\title{
MENELADANI ETOS KERJA RASULULLAH SAw
}

\author{
Ahmad Zaini \\ STAIN Kudus
}

\begin{abstract}
Abstrak
Human beings are given freedom to seek provision in accordance with applicable law and in a way that is fair. This is one of the obligations of human rights in Islam. Allah SWT. has established through the ordinance of him that any kind of work that run based on the principles of Koranic will never make one rich in a brief period of time. In the view of Islam, work not just as the pusher man to maintain their existence in life, but is the basis of all things. People began to work has been started since the Prophet Adam and his seed inhabiting the earth. She has been at pains to and hard to meet the needs of his life, while in paradise Adam got without the feeling of weariness and fatigue. So also the Prophet (saas. Is a hard worker through the efforts of trade he do when reselling merchandise owned by Siti Khadijah. The Messenger of Allah alone always tries to hit to all his people so that they have a high work ethos. Efforts done by Mohammed. So that the people of Islam have a high working ethos was not only shown through several hadith that he sabdakan, but also shown itself by Muhammad through a more real action. Muhammad showed himself as a person that ethnic high work, not easy to surrender, hard worker and reluctant to freaks who sit.
\end{abstract}

Key words: work, Islamic work ethos, Mohammed

\section{A. Pendahuluan}

Manusia merupakan makhluk Allah swt. yang diciptakan dalam bentuk yang paling baik sesuai dengan hakikat wujud manusia dalam kehidupan di dunia, yakni melaksanakan tugas kekhalifahan dalam kerangka pengabdian kepada Sang Mahapencipta, Allah swt. Sebagai khalifah-Nya di muka bumi, manusia diberi amanah untuk memberdayakan seisi alam raya dengan sebaik-baiknya demi kesejahteraan seluruh makhluk (Karim, 2006: 3).

Islam merupakan agama yang dibangun dengan bekerja dan tekad yang sungguh-sungguh, tidak mengenal adanya 
rahbaniyyah (kependetaan) dan memisahkan diri dari kehidupan dunia. Allah berfirman Qs. al-Hadid: 27).

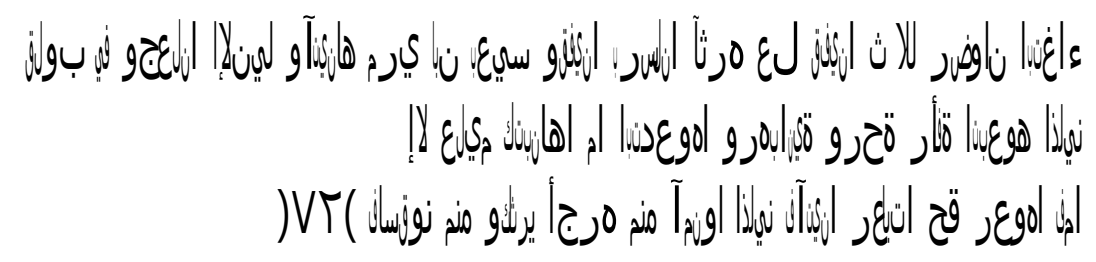

"Kemudian Kami susulkan rasul-rasul Kami mengikuti jejak mereka dan Kami susulkan (pula) Isa putra Maryam; dan Kami berikan Injil kepadanyadan Kami jadikan rasa santun dan kasih sayang dalam hati orang-orang yang mengikutinya. Mereka mengada-adakan rahbaniyyahpadahal Kami tidak mewajibkannya kepada mereka (yang Kami wajibkan hanyalah) mencari keridhaan Allah, tetapi tidak mereka pelihara dengan semestinya. Maka kepada orang-orang yang beriman di antara merekaKami berikan pahalanya dan banyak di antara mereka yang fasik."

Mahmud Syaltut seperti dikutip oleh Ahmad Ibrahim Abu Sinn (2006: 5) menjelaskan, "Bahwa manusia dan jin diciptakan Allah dalam kerangka ibadah kepada-Nya, namun demikian, hal ini tidak berarti harus mengasingkan diri dan menjauh dari kehidupan dunia. Cara ibadah yang sebenarnya adalah dengan membumikan kehendak Allah di muka bumi ini dengan melakukan pemakmuran dan pembangunan bumi. Menyingkap rahasia Allah yang menunjukkan keagungan dan keesaan-Nya dalam kerangka beribadah dan menyucikan-Nya."

Dalam rangka mengemban amanah sebagai khalifahNya, manusia diberi kebebasan untuk mencari nafkah sesuai dengan hukum yang berlaku serta dengan cara yang adil. Hal ini merupakan salah satu kewajiban asasi dalam Islam. Dengan demikian, pada dasarnya Islam mengakui kepemilikan pribadi. Islam tidak membatasi kepemilikan pribadi, alat-alat produksi, barang dagangan ataupun perdagangan, tetapi hanya melarang perolehan kekayaan melalui cara-cara yang ilegal atau tidak bermoral. Islam sangat menentang setiap aktivitas ekonomi yang bertujuan melakukan penimbunan kekayaan atau pengambilan keuntungan yang tidak layak dari kesulitan orang lain atau penyalahgunaannya (Karim, 2006: 29).

Allah swt. telah menetapkan melalui sunah-Nya bahwa 
jenis pekerjaan atau usaha apa pun yang dijalankan berdasarkan prinsip-prinsip Qurani tidak akan pernah menjadikan seseorang kaya raya dalam jangka waktu yang singkat. Kesuksesan seseorang dalam berusaha baru akan terwujud jika dilalui dengan kerja keras, ketekukan dan kesabaran disertai dengan doa yang tidak pernah terputus (Karim, 2006: 30). Dalam pandangan Islam, bekerja tidak hanya sekedar sebagai pendorong manusia untuk mempertahankan eksistensinya dalam kehidupan, namun merupakan asas segala sesuatu. Bekerja merupakan fondasi dasar untuk mendekatkan diri kepada Allah. Untuk itu, al-Quran senantiasa mengiringi lafal 'amal dengan lafal iman. Bekerja merupakan asas kehidupan Islam, Islam sangat mendorong setiap muslim untuk bekerja secara sungguh-sungguh dengan etos kerja tinggi, bekerja secara optimal dengan menghilangkan segala hambatan dan tantangan (al-Mishri, 2006: 6).

Orang mulai bekerja sudah dimulai sejak Nabi Adam dan anak cucunya mendiami bumi. Beliau telah bersusah payah dan membanting tulang memenuhi kebutuhan hidupnya, sedangkan di dalam surga Adam memperoleh semua itu tanpa perasaan penat dan letih. Pada dasarnya, Allah menciptakan manusia dengan tabiat yang terikat dengan kebutuhan akan makan, minum, pakaian, tempat tinggal, dan keturunan. Allah tidak menjadikan manusia makhluk rohani seperti malaikat, tidak juga jasad bisu seperti patung. Oleh sebab itu, tidak aneh jika manusia sampai para nabi membutuhkan usaha untuk memenuhi bagian itu. "Dan Kami tidak mengutus rasul-rasul sebelummu (Muhammad), melainkan mereka pasti memakan makanan dan berjalan di pasar-pasar. Dan Kami jadikan sebagian kamu sebagai cobaan bagi sebagian yang lain. Maukah kamu bersabar? Dan Tuhanmu Maha Melihat"(Qs. al-Furqan: 20) Setelah Allah menciptakan manusia dalam bentuk ini, Dia menurunkannya di bumi. Dia pun membekali manusia dengan sarana dan prasarana untuk melangsungkan kehidupannya, untuk mencapai tujuannya, serta melengkapinya dengan bakat, stamina, serta peralatan untuk memenuhi segala kebutuhan di bumi (Qardhawi, 1997: 106).

Demikian halnya Rasulullah saw. adalah seorang pekerja keras melalui usaha dagang yang beliau lakukan ketika menjualkan barang dagangan milik Siti Khadijah. Berpijak 


\section{Ahmad Zaini}

pada kenyataan bahwa Islam sama sekali tidak mengajarkan hidup miskin, maka Rasulullah sendiri selalu berusaha untuk menyadarkan kepada semua umatnya agar mereka memiliki etos kerja yang tinggi. Upaya ini dibuktikan dengan langkah-langkah Rasulullah dalam menanamkan ajaran tentang pandangan hidup yang benar mengenai kehidupan dunia. Langkah ini ditempuh Rasulullah dengan alasan bahwa pandangan hidup yang salah bagaimanapun juga akan melahirkan sebuah sikap yang salah pula. Dan inilah yang sering kali menjadi latar belakang mengapa seseorang tidak punya etos kerja yang tinggi (Nachrawie, 2011: 14-15).

Kerja keras merupakan modal dasar untuk keberhasilan seseorang. Rasulullah sangat marah melihat orang pemalas dan suka berpangku tangan. Bahkan, beliau secara simbolik memberi hadiah kampak dan tali kepada seorang lelaki agar mau bekerja keras mencari kayu dan menjualnya ke pasar. Demikian pula jika mau berusaha, mulailah berusaha sejak subuh. Jangan tidur sesudah subuh, cepatlah bangun dan mulailah kegiatan untuk hari itu. Akhirnya laki-laki itu sukses dalam hidupnya (Alma, 2014: 106). Karena itu, tulisan ini akan membahas tentang etos kerja Rasulullah saw. Pembahasan diawali dengan menjelaskan pengertian bekerja, etos kerja, anjuran bekerja, urgensi bekerja, dan tentunya bagaimana meneladani etos kerja Rasulullah saw.

\section{B. Pengertian Etos Kerja}

Islam memerintahkan setiap manusia untuk bekerja sepanjang hidupnya. Islam membagi waktu menjadi dua, yaitu beribadah dan bekerja mencari rezeki. Dalam arti sempit, kerja adalah pemanfaatan atas kepemilikan sumber daya manusia. Secara umum, kerja berarti pemanfaatan sumber daya, bukan hanya pemilikannya semata. Pemilik sumber daya, sumber daya alam misalnya, didorong untuk dapat memanfaatkannya dan hanya boleh mendapatkan kompensasi atas pemanfaatan tersebut. Islam melarang pemilik tanah memungut sewa atas tanah yang masih menganggur dan hanya membolehkannya ketika tanah tersebut telah diolah. Rezeki paling utama adalah rezeki yang diperoleh dari hasil kerja atau keringat sendiri, dan rezeki yang paling dibenci Allah adalah rezeki yang diperoleh dengan cara meminta-minta (Tim Penulis, 2008: 66). 
Yang dimaksud bekerja adalah segala usaha maksimal yang dilakukan manusia, baik lewat gerak anggota tubuh ataupun akal untuk menambah kekayaan, baik dilakukan secara perseorangan ataupun secara kolektif, baik untuk pribadi ataupun untuk orang lain (dengan menerima gaji). "Orang lain" ini bisa majikan, perusahaan swasta, atau bisa juga lembaga pemerintah. Pekerjaan itu bisa dilakukan dalam lapangan perkebunan, perindustrian, atau perdagangan, baik pekerjaan white collar (kerah putih) ataupun blue collar (buruh kasar). Produktivitas timbul dari gabungan kerja antara manusia dan kekayaan bumi. Bumi tempat membanting tulang, sedangkan manusia adalah pekerja di atasnya (Qardhawi, 1997: 105)

Selanjutnya yang dimaksud dengan etos kerja adalah suatu falsafah yang didasari oleh pandangan hidup atau sikap hidup sebagai nilai-nilai yang menjadi sifat, kebiasaan dan kekuatan pendorong, membudaya dalam kehidupan pribadi atau suatu kelompok masyarakat dan organisasi, kemudian tercermin dari sikap menjadi perilaku, kepercayaan, cita-cita, pendapat dan tindakan yang terwujud sebagai "kerja" atau "bekerja". Etos kerja harus didasarkan pada niat beribadah karena Allah dalam rangka mencarai ma'isyah dan fadhilah Allah dengan sungguh-sungguh mencarinya. Karenanya, dalam konteks Islam, etos kerja akan meningkatkan produktivitas seseorang. Karena jika produktivitas dipercaya mempunyai kaitan erat dengan etos kerja, maka etos kerja dipandang terkait dengan nilai-nilai yang dianut oleh seorang yang beragamanya kuat (Aziz, 2013: 122-123).

\section{Urgensi Kerja}

Islam sebagai sumber kebenaran telah memberikan ruang yang seluas-luasnya kepada umatnya untuk bekerja sepanjang yang dikerjakan tidak bertentangan dengan syariah. Syariah lah yang menjadi pedoman dan referensi utama ketika manusia mengerjakan sesuatu baik untuk dirinya maupun untuk orang lain. Allah swt. berfirman, "Dan katakanlah bekerjalah kamu, maka Allah dan Rasulnya dan orang-orang mukmin akan melihat pekerjaanmu itu, dan kamu akan dikembalikan kepada Allah Yang Maha Mengetahui Yang Gaib dan Yang Nyata, lalu Dia terangkan kepadamu tentang apa yang telah kamu kerjakan" (Qs. at-Taubah: 
105). Maksud perintah Allah swt. supaya manusia bekerja, namun tidak boleh lupa bahwa apapun yang dikerjakan akan dilihat oleh Allah dan Rasul-Nya, serta orang-orang mukmin yang bermakna penyaksian dan kelak akan diperhadapkan kembali kepada Allah swt. mengenai apa yang telah dikerjakan. Di sinilah makna penting jawaban manusia terhadap pekerjaan atau amal yang dilaksanakannya (Aedy, 2011: 84).

Berusaha dalam bidang bisnis dan perdagangan termasuk usaha kerja keras. Dalam kerja keras itu, tersembunyi kepuasan batin yang tidak dinikmati oleh profesi lain. Kemauan keras ini dapat menggerakkan motivasi untuk bekerja dengan sungguhsungguh. Orang-orang yang berhasil atau bangsa yang berhasil ialah bangsa yang mau kerja keras, tahan menderita, tapi berjuan terus memperbaiki nasibnya. Pekerjaan dakwah yang dilakukan oleh Rasul pun mencerminkan kerja keras, sehingga dapat berhasil mendapat kejayaannya. Dalam al-Quran dinyatakan bahwa, "Apabila engkau telah berazam, maka bertakwalah kepada Allah" (Qs. Ali Imran: 159). Kerja keras bukan yang dilakukan pada saat memulai saja, tetapi juga terus dilakukan walaupun kita sudah berhasil (Alma, 2003: 83).

Sebagai orang muslim kita dituntut agar tidak hanya mementingkan atau mengutamakan kerja keras untuk dunia saja atau akhirat saja, tetapi ditengah-tengah antara keduanya, maksudnya jangan sampai kita dilalaikan oleh pekerjaan mencari harta saja, tapi berusahalah dan selalu dekat kepada Allah swt. seperti dinyatakan dalam al-Quran surat al-Qashas ayat 77,"Dan carilah (pahala) negeri akhirat dengan apa yang telah dianugerahkan Allah kepadamu, tetapi jangan lupakan bagianmu di dunia dan berbuat baiklah (kepada orang lain) sebagaimana Allah telah berbuat baik kepadamu, dan janganlah kamu berbuat kerusakan di bumi. Sungguh, Allah tidak menyukai orang yang berbuat kerusakan."

Ajaran ini akan menggugah seorang muslim agar mau bekerja keras dalam segala bidang kehidupan, tidak hanya menyerah kepada nasib. Sebelum nasib tiba, kita harus berusaha lebih dulu dengan penuh tawakal kepada Allah. Allah tidak akan mengubah nasib seseorang apabila orang tersebut tidak berusaha dan tidak mau mengubah nasibnya sendiri. Jadi intinya ialah inisiatif, motivasi, kreatif, dan akhirnya akan meningkatkan produktivitas guna perbaikan kehidupan. Berusaha dan bekerja 
keras sangat ditekankan oleh Rasulullah saw., kita tidak boleh berpangku tangan, mengharap rezeki hanya dengan berdoa saja. Berdoa tanpa usaha tidak ada gunanya. Diriwayatkan bahwa Umar bin Khattab selesai salat menjumpai sekelompok orang yang membenamkan dirinya di masjid, dengan alasan tawakal dan berdoa kepada Allah, maka beliau memperingatkan: "Janganlah sekali-kali di antara kalian ada yang duduk-duduk malas mencari rezeki dan membaca doa Ya Allah limpahkanlah rezeki kepadaku, padahal mereka mengetahui bahwa dari langit tidak akan turun hujan emas dan perak."(Alma, 2014: 255-256).

Bahkan, Rasulullah sebagai utusan Allah dan penutup sekalian para Rasul, juga bekerja. Selain berdagang, beliau pernah menggembala kambing. Itu juga bukand kambingnya sendiri, tetapi ia menggembala dengan upah miliki sebagian penduduk Mekah. Diterangkannya hal ini kepada umatnya untuk mengajar mereka, bahwa kebesaran justru dimiliki oleh orang-orang yang suka bekerja, bukan oleh orang yang suka berfoya-foya tetapi menganggur. Al-Quran juga mengkisahkan kepada kita tentang kisah Nabi Musa a.s., bahwa dia pun bekerja sebagai buruh untuk seseorang yang sudah sangat tua. Dia bekerja sebagai buruh selama 8 tahun sebagai persyaratan untuk dikawinkan dengan salah seorang puterinya. Nabi Musa dinilai orang tua tersebut sebagai pekerja yang baik dan buruh yang terpuji. Maka benarlah firasat puteri orang tua itu, ketika ia mengatakan kepada bapaknya, Ya bapakku ambillah ia sebagai orang yang bekerja (pada kita), karena sesungguhnya orang yang paling baik yang kamu ambil untuk bekerja (pada kita) ialah orang yang kuat lagi dapat dipercaya" (Qs. al-Qashash: 26). Diriwayatkan oleh Ibnu Abbas, "bahwaNabi Daud bekerja sebagai tukang besi untuk membuat baju besi. Adam bekerja sebagai petani, Nuh sebagai tukang kayu, Idris sebagai penjahit, sedangkan Musa sebagai penggembala kambing" (HR. Hakim) (Qaradhawi, 2007: 140-141).

\section{Anjuran untuk Bekerja}

Bekerja adalah bagian dari ibadah dan jihad jika sang pekerja bersikap konsisten terhadap peraturan Allah, suci niatnya, dan tidak melupakan-Nya. Dengan bekerja, masyarakat bisa melaksanakan tugas kekhalifahannya, menjaga diri dari maksiat, dan meraih tujuan yang lebih besar. Demikian pula, 


\section{Ahmad Zaini}

dengan bekerja individu bisa memenuh kebutuhan hidupnya, mencukupi kebutuhan keluarganya, dan berbuat baik terhadap tetangganya. Semua bentuk yang diberkati agama ini hanya bisa terlaksana dengan memiliki harta dan mendapatkannya dengan bekerja. Maka tidak aneh jika kita menemukan nas-nas Islam yang mengajak umatnya untuk bekerja dan menjadikannya bagian dari ibadah dan jihad (Qardhawi, 1997: 107).

Berusaha dalam bidang bisnis dan perdagangan adalah salah satu usaha kerja keras. Dalam kerja keras itu, tersembunyi kepuasan batin, yang tidak dinikmati oleh profesi lain. Kemauan keras dapat menggerakkan motivasi untuk bekerja dengan sungguh-sungguh. Orang-orang atau bangsa yang berhasil ialah yang mau bekerja keras, tahan menderita, dan berjuang memperbaiki nasibnya. Bekerja keras bukan hanya dilakukan pada saat memulai saja, akan tetapi terus dilakukan walaupun sudah berhasil. Lakukan perbaikan terus-menerus atas apa yang telah dikerjakan dan jangan terlena karena suatu keberhasilan. Perbaikan pekerjaan terus-menerus banyak dicontohkan oleh orang Jepang dalam keseharian pekerjaan mereka, dengan apa yang disebut Kaizen yang berarti unending improvement (perbaikan terus-menerus, tak pernah berhenti). Dengan konsep ini, produk yang dihasilkan oleh industri Jepang selalu ada perbaikan, selalu ada model baru. Konsep Kaizen dilakukan merata di seluruh bidang kehidupan (Alma, 2014: 254-255).

Al-Quran telah menjelaskan bahwa manusia didesak untuk bekerja. Semua insentif yang ada diperuntukkan untukmanusia agar dia terlibat dalam semua aktivitas yang produktif.

\section{Janji Pahala}

Al-Quran mendesak kerja keras dan menjanjikan pertolongan Allah dan petunjuk-Nya bagi mereka yang berjuang dan berlaku baik. Dalam banyak ayatnya, al-Quran menjanjikan pahala yang berlimpah bagi seorang yang bekerja dengan memberikan pada mereka tuntutan insentif untuk meningkatkan kualitas dan kuantitas kerjanya.

\section{Anjuran untuk Terampil dan Menguasai Teknologi}

Al-Quran menganjurkan pada manusia untuk memiliki keterampilan dan menguasai teknologi dengan menyebutnya sebagai fadhl (keutamaan, karunia) Allah. Al- 
Quran juga mendesak mereka untuk mempergunakan besi dengan sebaik-baiknya, yang dalam pandangan al-Quran, memiliki sebuah sumber kekuatan yang signifikan dan memiliki banyak manfaat bagi manusia.

\section{Pandangan Positif terhadap Kerja untuk Kehidupan}

Al-Quran juga menyerukan pada semua orang yang memiliki kemampuan fisik untuk bekerja dalam usaha mencari sarana hidup untuk dirinya sendiri. Tak seorangpun dalam situasi normal, dibolehkan untuk meminta-minta atau menjadi beban kerabat dan negara sekalipun. Al-Quran sangat menghargai mereka yang berjuang untuk mencapai dan memperoleh karunia Allah. Apa yang disebut karunia ini adalah meliputi segala macam sarana kehidupan.

\section{Respek terhadap Kerja dan Pekerja}

Islam menghormati segala bentuk pekerjaan untuk menghasilkan sarana hidup sepanjang tidak ada ketidaksenonohan dan tindakan yang salah dan merugikan. Perlu dijelaskan juga bahwa kerja yang diwajibkan dan dianjurkan Islam adalah kerja yang saleh (amal saleh), yang baik dan produktif serta membawa manfaat. Bukan sembarang kerja. Maka, setiap ajakan kerja dalam alQuran akan selalu dibarengi dengan sifat yang saleh dan baik. Yang juga pantas untuk menjadi catatan adalah bahwasannya semua pekerjaan, baik yang baik maupun yang buruk pastilah dimintai pertanggungjawabannya. Hal ini bisa dilihat dalam surat al-Zalzalah ayat 6-8 (Ahmad, 2006: 13-15).

\section{E. Motivasi Diwajibkannya Bekerja}

Umat Islam dituntut untuk tidak hanya mementingkan akhirat, namun juga meraih kebahagiaan dunia. Sehingga perlu ada keseimbangan dan sinergi antara kehidupan dunia dan akhirat. Allah swt. berfirman dalam surat al-Qashas ayat 77,

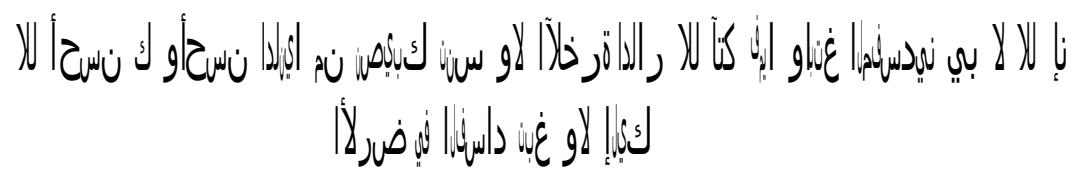

"Dan carilah (pahala) negeri akhirat dengan apa yang telah dianugerahkan Allah kepadamu, tetapi jangan lupakan bagianmu di 


\section{Ahmad Zaini}

dunia dan berbuat baiklah (kepada orang lain) sebagaimana Allah telah berbuat baik kepadamu, dan janganlah kamu berbuat kerusakan di bumi. Sungguh, Allah tidak menyukai orang yang berbuat kerusakan."

Islam melarang umatnya menyia-nyiakan orang yang berada di bawah tanggungannya, dimana ia tidak memenuhi kebutuhan hidup anak istrinya sesuai dengan kemampuan usaha yang ia lakukan. Ajaran-ajaran ini akan menggugah seorang muslim agar mau bekerja keras dalam segala bidang kehidupan, tidak hanya menyerah kepada nasib. Sebelum nasib tiba, kita harus berusaha terlebih dahulu dengan penuh tawakal kepada Allah swt. Allah swt. tidak akan mengubah nasib seseorang, apabila orang itu tidak berusaha, dan tidak mau mengubah nasibnya sendiri. Intinya ialah inisiatif, motivasi, kreatif, dan akhirnya akan meningkatkan produktivitas guna perbaikan kehidupan (Alma dan Priansa, 2014: 327-328).

Pada dasarnya orang bekerja dan berwirausaha selain untuk beribadah tetapi juga untuk mencari untung sebagaimana para pedagang para umumnya. Orang bekerja dan berwirausaha keuntungannya juga dapat dijadikan sebagai sarana mendekatkan diri kepada Allah swt. Dalam melakukan aktivitas kerja dan usaha, mereka mendasarkannya pada fungsi hidup yang digariskan Allah dalam al-Quran, yakni ta'abbud, menghambakan diri kepada Allah swt. (Abdurrahman, 2013: 165-166).

Menurut Yusuf Qardhawi (1997: 109-112) motivasi diwajibkannya bekerja karena alasan-alasan berikut ini:

Pertama, untuk mencukupi kebutuhan hidup. Berdasarkan tuntutan syariat, seorang muslim diminta bekerja untuk mencapai beberapa tujuan. Yang pertama adalah untuk memenuhi kebutuhan pribadi dengan harta yang halal, mencegahnya dari kehinaan meminta-minta, dan menjaga tangannya agar tetap berada di atas. Dampak diwajibkannya bekerja bagi individu oleh Islam adalah dilarangnya memintaminta, mengemis, dan mengharapkan belas kasihan orang. Mengemis tidak dibenarkan kecuali dalam tiga kasus: menderita kemiskinan yang melilit, memiliki utang yang menjerat, dan diyah murhiqah (menanggung beban melebihi kemampuan untuk menebus pembunuhan).

Kedua, untuk kemaslahatan keluarga. Bekerja diwajibkan 
demi terwujudnya keluarga. Islam mensyariatkan seluruh manusia untuk bekerja, baik laki-laki ataupun wanita, sesuai dengan profesi masing-masing. "Laki-laki penjaga bagi keluarganya dan ia bertanggung jawab atas asuhannya, wanita pengasuh bagi rumah suaminya dan ia bertanggung jawab atas asuhannya."(HR. Muttafaqun 'Alaih) "Cukuplah dosa seseorang karena menelantarkan orang yang menjadi tanggungannya dalam memberi makan." AlQuran mengisahkan dua orang pekerja wanita yang dibantu oleh Musa dengan cara memberi minum kepada hewan ternaknya. Kedua wanita itu bertugas memelihara domba keluarga. Tentang ayahnya yang sudah sangat tua, kedua wanita itu berkata, “... Kami tidak dapat memberi minum (ternak kami), sebelum pengembalapengembala itu memulangkan (ternaknya), sedang ayah kami adalah orang tua yang telah lanjut usianya" (Qs. al-Qashash: 23).

Ketiga, untuk kemaslahatan masyarakat. Walaupun seseorang tidak membutuhkan pekerjaan karena seluruh kebutuhan hidupnya telah tersedia, baik untuk dirinya maupun untuk keluarganya ia tetap wajib bekerja untuk masyarakat sekitarnya. Karena masyarakat telah memberikan sumbangsih yang tidak sedikit kepadanya, maka seyogyanya masyarakat mengambil darinya sebanyak apa yang diberikan kepadanya. Alangkah indahnya tindakan ulama yang menjadikan pekerjaan duniawi sebagai perbuatan wajib menurut syariah, ditinjau dari kemaslahatan masyarakat.

Keempat,hidup untuk kehidupan dan untuk semua yang hidup. Lebih dari itu, seorang muslim tidak hanya bekerja demi mencapai manfaat komunitas manusia, tetapi ia wajib bekerja untuk kemanfaatan seluruh makhluk hidup, termasuk hewan. Nabi berkata, "Pada setiap yang punya hati suatu pahala diperbuatnya" (HR. Bukhari dan Muslim). "Siapakah dari kaum muslimin yang menanam tanaman atau tumbuh-tumbuhan lalu dimakan oleh burung, manusia atau hewan, kecuali baginya sedekah" (HR. Bukhari dan Muslim).

Kelima,bekerja untuk memakmuran bumi. Bekerja sangat diharapkan dalam Islam untuk memakmurkan bumi. Memakmurkan bumi adalah tujuan dari maqasidus syari'ah yang ditanam oleh Islam, disinggung oleh al-Quran serta diperhatikan oleh para ulama. Di antara mereka menurut Yusuf Qardhawi adalah Imam ar-Raghib al-Asfahani yang menerangkan bahwa 
manusia diciptakan Allah hanya untuk tiga kepentingan, yaitu: a) memakmurkan bumi, seperti tertera dalam al-Quran, "Dia telah menciptakan kamu dari bumi (tanah) dan menjadikan kamu pemakmurnya" (Qs. Hud: 61). Maksudnya, manusia dijadikan penghuni dunia untuk menguasai dan memakmurkan dunia, $b$ ) menyembah Allah, sesuai dengan firman-Nya: "Dan Aku tidak menciptakan jin dan manusia melainkan supaya mereka menyembahKu" (Qs. adz-Dzariyat: 56), c) sebagai khalifah, sesuai dengan firman-Nya, "Dan menjadikan kamu khalifah di bumi-(Nya), maka Allah akan melihat perbuatanmu" (Qs. al-A'raf: 129).

Keenam, bekerja untuk bekerja. Menurut Islam, pada hakikatnya setiap muslim diminta untuk bekerja meskipun hasil pekerjaannya belum dapat dimanfaatkan olehnya, oleh keluarganya atau oleh masyarakat, juga meskipun tidak satu pun dari makhluk Allah, termasuk hewan, dapat memanfaatkannya. Ia tetap wajib bekerja karena bekerja merupakan hak Allah dan salah satu cara mendekatkan diri kepada-Nya. Pondasi yang kokoh ini kita temukan pada hadis Nabi yang diriwayatkan oleh Anas, "Apabila hari kiamat datang dan pada tangan seorang di antara kamu ada biji untuk ditanam, maka jika ia bisa menanamnya, tanamlah sebelum tiba kiamat."

\section{F. Etos Kerja Islami}

Menurut Toto Tasmara penulis buku Membudayakan Etos Kerja Islami dijelaskan bahwa ada 25 ciri etos kerja bagi seorang muslim. Ciri-ciri orang yang memiliki dan menghayati etos kerja akan tampak dalam sikap dan tingkah lakunya yang dilandaskan pada suatu keyakinan yang sangat mendalam bahwa bekerja itu ibadah dan berprestasi itu indah. Namun, pada tulisan ini penulis hanya mengutip sebagian saja yang penulis sarikan dari pendapat Toto Tasmara (2002: 73-107), di antaranya adalah:

\section{Mereka Kecanduan terhadap waktu}

Salah satu esensi dan hakikat etos kerja adalah cara seseorang menghayati, memahami, dan merasakan betapa berharganya waktu. Satu detik berlalu tidak mungkin dia kembali. Waktu merupakan deposito paling berharga yang dianugerahkan Allah swt. secara gratis dan merata kepada setiap orang. Salah satu ciri orang modern adalah mereka yang menyikapi waktu dengan sangat bersungguh- 
sungguh.

\section{Memiliki Moralitas yang Bersih (Ikhlas)}

Salah satu kompetensi moral yang dimiliki seorang yang berbudaya kerja Islami itu adalah nilai keikhlasan. Ikhlas yang terambil dari bahasa Arab mempunyai arti: bersih, murni, sebagai antonim dari syirik. Orangnya disebut mukhlis. Mereka yang disebut mukhlis melaksanakan tugasnya secara profesional tanpa motivasi kecuali bahwa pekerjaan itu merupakan amanat yang harus ditunaikannya sebaik-baiknya dan memang begitulah seharusnya. Motivasi unggul yang ada hanyalah pamrih pada hati nuraninya sendiri (conscience). Kalaupun ada reward atau imbalan, itu bukanlah tujuan utama, melainkan sekadar akibat sampingan (side effect) dari pengabdian dirinya yang murni tersebut.

\section{Memiliki Kejujuran}

Perilaku yang jujur adalah perilaku yang diikuti oleh sikap tanggung jawab atas apa yang diperbuatnya tersebut atau integritas. Kejujuran dan integritas bagaikan dua sisi mata uang. Seseorang tidak cukup hanya memiliki keikhlasan dan kejujuran, tetapi dibutuhkan pula nilai pendorong lainnya, yaitu integritas. Akibatnya, mereka siap menghadapi risiko dan seluruh akibatnya dia hadapi dengan gagah berani, kebanggaan, dan penuh sukacita, dan tidak pernah terpikirkan untuk melemparkan tanggung jawabnya kepada orang lain. Hal ini karena sikap tidak bertanggung jawab merupakan pelecehan paling asasi terhadap orang lain dan sekaligus penghinaan terhadap dirinya sendiri dan Tuhan.

\section{Konsekuen dan Berani Menghadapi Tantangan}

Orang yang memiliki etos kerja Islami adalah keberaniannya menerima konsekuensi dari keputusannya. Bagi mereka, hidup adalah pilihan dan setiap pilihan merupakan tanggung jawab pribadinya. Mereka tidak mungkin menyalahkan pihak manapun karena pada akhirnya semua pilihan ditetapkan oleh dirinya sendiri. 


\section{Ahmad Zaini}

Orang yang konsekuen memiliki kemampuan untuk melakukan pengendalian dan mengelola emosinya menjadi daya penggerak positif untuk tetap semangat menapaki keyakinannya.

\section{Memiliki Kepercayaan Diri}

Pribadi muslim yang percaya diri tampil bagaikan lampu yang benderang, memancarkan raut wajah yang cerah dan berkharisma. Orang-orang yang berada di sekitarnya merasa tercerahkan, optimis, tenteram, dan muthmainnah. Percaya diri melahirkan kekuatan, keberanian, dan tegas dalam bersikap. Berani mengambil keputusan yang sulit walaupun harus membawa konsekuensi berupa tantangan atau penolakan.

\section{Kreativitas}

Pribadi muslim yang kreatif selalu ingin mencoba metode atau gagasan baru dan asli sehingga diharapkannya hasil kinerja dapat dilaksanakan secara efisien, tetapi efektif. Seorang yang kreatif bekerja dengan informasi, data, dan mengolahnya sedemikian rupa sehingga memberikan hasil atau manfaat yang besar. Hidup bagaikan kanvas lukisan yang mendorong dan memanggil nuraninya untuk melukiskan gambar-gambar yang paling indah. Setiap hari adalah sebuah kegairahan untuk menjadikan dirinya memetik manfaat.

\section{Memiliki Jiwa Kepemimpinan}

Memimpin berarti mengambil peran secara aktif untuk memengaruhi dirinya sendiri dan memberikan inspirasi teladan bagi orang lain. Seorang pemimpin adalah seorang yang mempunyai personalitas yang tinggi. Dia larut dalam keyakinannya, tetapi tidak segan untuk menerima kritik, bahkan mengikuti apa yang terbaik. Integritasnya terhadap keyakinan tauhid itulah yang menyebabkan dia bagaikan batu karang yang tidak mudah goncang walaupun dia berada di pihak minoritas karena bagi dirinya, ukuran kebenaran tidak ditentukan oleh sejumlah mayoritas. 


\section{Berorientasi ke Masa Depan}

Seorang pribadi muslim yang memiliki etos kerja harus menetapkan sesuatu yang jelas dan karenanya seluruh tindakannya diarahkan kepada tujuan yang telah dia tetapkan. Seperti ilmu tanaman: siapa yang menanam, dia yang menuai. Begitulah cara berpikir seorang pribadi muslim. Dia harus menanam sesuatu yang sudah dia rencanakan, kapan dan apa hasil yang akan dia peroleh dari upayanya menabur benih tersebut.

\section{Memiliki Jiwa wiraswasta}

Dia memiliki jiwa wiraswasta yang tinggi, yaitu kesadaran dan kemampuan yang sangat mendalam untuk melihat segala fenomena yang ada di sekitarnya, merenung, dan kemudian bergelora semangatnya untuk mewujudkan setiap perenungan batinnya dalam bentuk yang nyata dan realistis. Nuraninya sangat halus dan tanggap terhadap lingkungan dan setiap tindakannya diperhitungkan dengan laba-rugi, manfaat atau mudharat (entrepreneurship).

\section{G. Meneladani Etos Kerja Rasulullah saw.}

Upaya keras yang dilakukan Rasulullah saw. agar umat Islam punya etos kerja yang tinggi ternyata bukan saja ditunjukkan lewat beberapa hadis yang beliau sabdakan, akan tetapi juga ditunjukkan sendiri oleh Rasulullah lewat tindakan yang lebih nyata. Rasulullah menunjukkan diri sebagai seseorang yang beretos kerja tinggi, tak mudah menyerah, pekerja keras dan enggan untuk bermalas-malasan. Dan hal ini bisa dilihat dari sejarah perjalanan Rasulullah, utamanya sebelum beliau dinobatkan sebagai Rasulullah. Dalam literatur sejarah disebutkan bahwa di sekitar masa mudanya, Rasulullah sudah sering mengikuti pamannya berdagang ke Syam dan Syiria pada usia 12 tahun. Lebih dari dua puluh tahun Rasulullah berkiprah di bidang wirausaha ini, sehingga beliau dikenal di Yaman, Syiria, Basrah, Irak, Yordania, dan kota-kota perdagangan di Jazirah Arab (Nachrawie, 2011: 25-26).

Sebagaimana diketahui bahwa Rasulullah dibesarkan oleh pamannya Abu Thalib. Pamannya ini bukanlah orang 


\section{Ahmad Zaini}

kaya, ia termasuk keluarga miskin dengan jumlah anggota besar yang harus dihidupi. Keadaan dan kondisi keluarga seperti ini mendorong Rasulullah untuk bekerja memenuhi nafkah dan membantu meringankan beban pamannya. Karena Rasulullah dibesarkan di lingkungan kaum Quraisy yang profesinya berdagang, maka pada diri Rasulullah juga mengalir bakat dagang (Alma, 2003: 14).

Agaknya, profesi sebagai pedagang ini telah dimulai lebih awal daripada yang dikenal umum dengan modal dari Khadijah. Ketika merintis karirnya tersebut, beliau memulai dengan berdagang kecil-kecilan di kota Mekah. Beliau membeli barang-barang dari satu pasar kemudian menjualnya kepada orang lain. Sampai kemudian beliau menerima modal dari para investor dan juga para janda kaya. Dalam melaksanakan bisnisnya tersebut, beliau memperkaya diri dengan kejujuran, keteguhan memegang janji, dan sifat-sifat mulia lainnya. Akibatnya, penduduk Mekah mengenal Rasulullah sebagai seorang yang terpercaya (al-amin) (Antonio, 2007: 81-82).

Satu hal yang harus disadari bahwa kesuksesan Rasulullah dalam hal berbisnis tentu tidak lepas dari tingkat etos kerja Rasulullah yang begitu tinggi. Nabi sadar betul bahwa hidup di dunia pasti dihadapkan oleh sebuah kenyataan bahwa kebutuhan hidup itu tidak sedikit. Maka dari itu hidup tidak bisa dibuat santai tanpa berfikir bagaimana caranya bisa memenuhi kebutuhan hidup hingga tidak menyusahkan orang lain. Kepribadian Muhammad saw. yang jujur, giat bekerja dan tidak suka bermalas-malasan adalah sebuah teladan. Itu adalah sebuah contoh baik yang sudah semestinya kita tiru (Nachrawie, 2011: 28).

Selain beliau memiliki etos kerja yang tinggi, Rasulullah saw. ketika bekerja sebagai pedagang, beliau menunjukkan dirinya sebagai pedagang yang profesional dan jujur.Dalam transaksi bisnisnya tidak ada pertengkaran antara beliau dengan para pelanggannya, sebagaimana sering disaksikan pada waktu itu di pasar-pasar di sepanjang Jazirah Arab. Segala permasalahan antara beliau dan pelanggannya selalu diselesaikan dengan damai dan adil, tanpa ada kekhawatiran akan terjadi unsur-unsur penipuan di dalamnya. Adalah fakta bahwa Rasulullah tidak hanya melakukan perdagangan dengan 
adil dan jujur, tetapi bahkan telah meletakkan prinsip-prinsip dasar untuk hubungan dagang yang adil dan jujur tersebut. Kejujuran, keadilan dan konsistensi yang beliau pegang teguh dalam transaksi-transaksi perdagangan telah menjadi teladan abadi dalam segala jenis masalah perdagangan (Kartajaya dan Sula, 2006: 49).

Kejujuran merupakan sifat penting dalam bisnis, Rasulullah sangat menganjurkan bagi para pedagang untuk bertindak secara jujur. Beliau sangat serius memerhatikan kejujuran, sehingga dalam sebuah wasiat, beliau mengingatkan bagi para pedagang yang suka berbohong tidak akan menerima berkah dalam usahanya. Diriwayatkan dari Imam Bukhari, Rasulullah saw. bersabda, "Penjual dan pembeli masih dalam khiyar sepanjang belum berpisah, jika keduanya jujur dan berterus terang, maka akan diberkahi dalam perdagangannya, dan jika keduanya menyembunyikan sesuatu dan berbohong, maka akan dihilangkan keberkahan dalam jual beli yang dilakukan." (Al-Mishri, 2006: 90).

\section{H. Simpulan}

Dari paparan di atas maka dapat disimpulkan bahwa Islam merupakan agama yang dibangun dengan bekerja dan tekad yang sungguh-sungguh, tidak mengenal adanya rahbaniyyah (kependetaan) dan memisahkan diri dari kehidupan dunia, seperti dijelaskan dalam firman Allah dalam surat alHadid di atas. Dalam rangka mengemban amanah sebagai khalifah-Nya, manusia diberi kebebasan untuk mencari nafkah sesuai dengan hukum yang berlaku serta dengan cara yang adil. Hal ini merupakan salah satu kewajiban asasi dalam Islam.

Islam memerintahkan setiap manusia untuk bekerja sepanjang hidupnya. Islam membagi waktu menjadi dua, yaitu beribadah dan bekerja mencari rezeki. Dalam arti sempit, kerja adalah pemanfaatan atas kepemilikan sumber daya manusia. Secara umum, kerja berarti pemanfaatan sumber daya, bukan hanya pemilikannya semata. Islam menganjurkan untuk memiliki etos kerja yang tinggi. Etos kerja harus didasarkan pada niat beribadah karena Allah dalam rangka mencarai ma'isyah dan fadhilah Allah dengan sungguh-sungguh mencarinya. Karenanya, dalam konteks Islam, etos kerja akan meningkatkan produktivitas seseorang. 


\section{Ahmad Zaini}

Di antara tujuan diwajibkannya orang bekerja adalah: pertama, untuk mencukupi kebutuhan pribadi supaya tidak mengemis dan dan mengharapkan belas kasihan orang, kedua, untuk kemaslahatan keluarga, terlebih seorang ayah berkewajiban untuk menafkahi istri dan anak-anaknya, ketiga, untuk kemaslahatan masyarakat, karena masyarakat dapat mengambil manfaat darinya, keempat, hidup untuk kehidupan dan untuk semua yang hidup, kelima, bekerja untuk memakmuran bumi.

Seorang muslim dalam bekerja harus meneladani etos kerja yang telah dicontohkan oleh uswatun hasanah terbaik yaitu Rasulullah saw. Beliau tidak hanya memerintah saja melalui sabdanya, namun sebelum beliau diangkat menjadi Rasul, sejak usia 12 tahun telah berdagang bersama pamannya hingga ke negeri Syam. Selain itu, beliau juga menjualkan barang dagangan milik Siti Khadijah yang di kemudian hari menjadi istri beliau. Etos kerja yang dimiliki oleh Rasulullah juga dibarengi dengan kejujuran dalam setiap transaksi dagangnya. Beliau telah memberikan nasihat kepada umatnya agar ketika bekerja dilandasi dengan kejujuran. Nabi-nabi sebelum Rasulullah saw. pun juga dikenal dengan giat bekerja. Semisal Nabi Musa a.s., bekerja sebagai buruh untuk seseorang yang sudah sangat tua, Nabi Nabi Daud bekerja sebagai tukang besi untuk membuat baju besi, Nabi Adam bekerja sebagai petani, Nuh sebagai tukang kayu, Idris sebagai penjahit dan sebagainya 


\section{DAFTAR PUSTAKA}

Ahmad Ibrahim Abu Sinn, Manajemen Syariah: Sebuah Kajian Historis dan Kontemporer, penerjemah Dimyauddin Djuwaini,Jakarta: PT RajaGrafindo Persada, 2006.

Adiwarman Azwar Karim, Sejarah Pemikiran Ekonomi Islam, Jakarta: PT RajaGrafindo Persada, 2006.

Mustaq Ahmad, Etika Bisnis dalam Islam, penerjemah Samson Rahman, Jakarta: Pustaka al-Kautsar, 2006.

Abdul Aziz, Etika Bisnis Perspektif Islam: Implementasi Etika Islami untuk Dunia Usaha, Bandung: Alfabeta, 2013.

Buchari Alma dan Donni Juni Priansa, Manajemen Bisnis Syariah: Menanamkan Nilai dan Praktik Syariah dalam Bisnis Kontemporer, Bandung: Alfabeta, 2014.

2003. Dasar-Dasar Etika Bisnis Islami, Bandung: Alfabeta, , Kewirausahaan,Bandung: Alfabeta, 2014.

Abdul Sami' al-Mishri, Pilar-Pilar Ekonomi Islam, penerjemah Dimyauddin Djuwaini, Yogyakarta: Pustaka Pelajar, 2006.

Tim Penulis, Ekonomi Islam, Jakarta: PT RajaGrafindo Persada, 2008.

H. M. Ma'ruf Abddullah, Wirausaha Berbasis Syari'ah, Yogyakarta: Aswaja Pressindo, 2013.

Nachrawie AS, Menggapai Rizki dengan Berbisnis Yang Barokah: Kiat Sukses Bisnis menurut Ajaran Nabi Muhammad saw., Delta

Prima

Karya, 2011. 
Ahmad Zaini

Nana Herdiana Abdurrahman, Manajemen Bisnis Syariah dan Kewirausahaan, Bandung: CV Pustaka Setia, 2013.

Yusuf Qaradhawi, Halal dan Haram, diterjemahkan oleh Tim Kuadran dari Halal wal Haram fil Islam, Bandung: Jabal, 2007.

Hasan Aedy, Teori dan Aplikasi Etika Bisnis Islam, Bandung: Alfabeta, 2011. 
Jurnal Bisnis dan Manajemen Islam 